\title{
Antidiabetic, Antimicrobial, and Molecular Profiling of Selected Medicinal Plants
}

\author{
Babita Aryal $\left(\mathbb{D},{ }^{1}\right.$ Purushottam Niraula $\left(\mathbb{D},{ }^{1}\right.$ Karan Khadayat ${ }^{(D)},{ }^{1}$ Bikash Adhikari $(D)$, \\ Dadhiram Khatri Chhetri $\mathbb{D}^{1},{ }^{1}$ Basanta Kumar Sapkota $\mathbb{D}^{1},{ }^{1}$ Bibek Raj Bhattarai $\mathbb{D}$, ${ }^{1}$ \\ Niraj Aryal $\mathbb{D}^{2}{ }^{2}$ and Niranjan Parajuli $\mathbb{D}^{1}$ \\ ${ }^{1}$ Biological Chemistry Lab, Central Department of Chemistry, Tribhuvan University, Kirtipur, Nepal \\ ${ }^{2}$ Pharmaceutical Institute, Department of Pharmaceutical Biology, University of Tübingen, Tübingen, Germany \\ Correspondence should be addressed to Niranjan Parajuli; niranjan.parajuli@cdc.tu.edu.np
}

Received 23 February 2021; Accepted 13 April 2021; Published 7 May 2021

Academic Editor: Riaz Ullah

Copyright (C) 2021 Babita Aryal et al. This is an open access article distributed under the Creative Commons Attribution License, which permits unrestricted use, distribution, and reproduction in any medium, provided the original work is properly cited.

\begin{abstract}
Natural products have been the center of attraction ever since they were discovered. Among them, plant-based natural products were popular as analgesics, anti-inflammatory, antidiabetic, and cosmetics and possess widespread biotechnological applications. The use of plant products as cosmetics and therapeutics is deep-rooted in Nepalese society. Although there are few ethnobotanical studies conducted, extensive research of these valuable medicinal plants has not been a priority due to the limitation of technology and infrastructure. Here, we selected 4 traditionally used medicinal plants to examine their bioactive properties and their enzyme inhibition potential. $\alpha$-Glucosidase and $\alpha$-amylase inhibitory activities were investigated using an in vitro model followed up by antioxidant and antimicrobial activities. The present study shows that ethyl acetate fraction of Melastoma melabathrium (IC ${ }_{50}$ $9.1 \pm 0.3 \mu \mathrm{g} / \mathrm{mL}$ ) and water fraction Acacia catechu $\left(\mathrm{IC}_{50} 9.0 \pm 0.6 \mu \mathrm{g} / \mathrm{mL}\right)$ exhibit strong $\alpha$-glucosidase inhibition. Likewise, the highest $\alpha$-amylase inhibition was shown by crude extracts of Ficus religiosa $\left(\mathrm{IC}_{50} 29.2 \pm 1.2 \mu \mathrm{g} / \mathrm{mL}\right.$ ) and ethyl acetate fractions of Shorea robusta $\left(\mathrm{IC}_{50} 69.3 \pm 1.1 \mu \mathrm{g} / \mathrm{mL}\right.$ ), and the highest radical scavenging activity was shown by $F$. religiosa with an $\mathrm{IC}_{50}$ $67.4 \pm 0.6 \mu \mathrm{g} / \mathrm{mL}$. Furthermore, to identify the metabolites within the fractions, we employed high-resolution mass spectrometry (LC-HRMS) and annotated 17 known metabolites which justify our assumption on activity. Of 4 medicinal plants examined, ethyl acetate fraction of $S$. robusta, ethyl acetate fraction of $M$. melabathrium, and water or ethyl acetate fraction of $A$. catechu extracts illustrated the best activities. With our study, we set up a foundation that provides authentic evidence to the community for use of these traditional plants. The annotated metabolites in this study support earlier experimental evidence towards the inhibition of enzymes. Further study is necessary to explore the clinical efficacy of these secondary molecules, which might be alternatives for the treatment of diabetes and pathogens.
\end{abstract}

\section{Background}

Natural products have gained significant appreciation as an alternative and/or complementary healthcare approach with extensive pharmaceutical and biological properties $[1,2]$. Worldwide, more than 900 medicinal plants are used for the cure of diabetes by different traditional practices like Ayurveda, Homeopathy, Amchi, Unani, Sidha, Chinese medicine, and folklore [3]. Although a very small number of plants are investigated for the treatment of pathogens, it is found more effective than synthetic drugs [4]. Diversities of secondary metabolites in plants are affected by various factors such as climate, harvest time, storage conditions, genetics, and variability [5].

In Nepal, more than 700 plant species constitute medicinal properties. They are used by different ethnic communities as a local source of medicine mostly called Ayurveda or Homeopathy [6]. As Nepal is climatically diverse, medicinal plants have massive attention among researchers for metabolic enzyme inhibition for the cure of infectious diseases. Proper understanding of traditional knowledge and research over them using more scientific 
methods might lead to the subsequent treatment of multiple diseases [7]. Diabetes and pathogens are postulated to have a high risk of emergence in Southeast Asia (SEA) [8, 9]. Because of diabetes, 1.2 million people died in SEA in 2019 [8]. The death rate of people dying with infectious diseases is very high [9]. Medicinal plants possess immune-modulatory and antioxidant properties, leading to antibacterial activities. They are known to have versatile immune-modulatory activities by stimulating both nonspecific and specific immunity [10]. Phytochemicals such as vitamins (A, C, E, and $\mathrm{K})$, carotenoids, terpenoids, flavonoids, polyphenols, alkaloids, tannins, saponins, pigments, enzymes, and minerals have hypercholesterolemic, anti-inflammatory, analgesic, antidiabetic, antimicrobial, antiplaque, antihypertensive, and anthelmintic activities [11-14].

The desorption/ionization methods for mass spectrometry had been technologically advanced for chemical identification over the past decades [15]; however, the characterization of plant extract using mass spectrometry is relatively difficult due to the lack of reliable extraction procedures [13, 14, 16]. Quadruple time-of-flight liquid chromatography-mass spectroscopy (Q-TOF LC/MS) technology provides an outstanding separation of major and trivial constituents of natural product extracts along with increasing selectivity and avoiding false-positive findings $[17,18]$. This high level of performance allows the elemental composition of each $\mathrm{m} / \mathrm{z}$ value to be accurately calculated using the software. The high mass resolution of up to 20,000 makes it useful for exact mass measurement as well as for molecular formula generation of any unknown molecule, parent ion, and fragment ion in the plant extracts [19]. This method is rapidly becoming an effective analytical tool to annotate compounds within a short time frame and with high sensitivity. In this study, we prioritized four medicinal plants in Nepal. Along with bioactivity studies, we also characterized/annotated molecules via LCHRMS. Further purification and characterization of therapeutically novel molecules could be the subject of future work.

\section{Materials and Methods}

2.1. Chemicals. The $\alpha$-glucosidase enzyme (CAS No.: 900142-7), 4-nitrophenyl $\alpha$-D-glucopyranoside (CAS No.: 3767-28-0), $\alpha$-amylase (CAS No.: 9000-90-2), 2-chloro-4nitrophenyl- $\alpha$-D-maltotrioside (CAS No.:118291-90-0), acarbose (CAS No.: 56180-94-0), and quercetin (CAS No.: 117-39-5) were purchased from Sigma-Aldrich (Germany). Gallic acid and 2,2-diphenyl-1-picrylhydrazyl (DPPH) were purchased from Molychem (India) and Himedia (India), respectively. Dimethyl sulphoxide, sodium dihydrogen orthophosphate, and other chemicals were purchased from Fisher Scientific (India).

2.2. Collection of Plant Materials. Parts of the plants taken under study were collected based on ethnobotanical and traditional medicinal uses of local healers from different areas of Nepal during May-December 2020. Herbarium specimens were deposited at the Central Department of Botany, Tribhuvan University. The list of medicinal plants selected for the study and their ethnopharmacological applications is shown in Table 1 . The plants obtained were airdried in the shade at room temperature and ground into a fine powder.

2.3. Preparation of Crude Extracts and Fractionation. The plant materials were shade-dried and ground into a fine powder. Extraction was done by the cold percolation method. Briefly, the powder of different plants was soaked in methanol for 24 hours at room temperature for three successive days. After 24 hours, the dissolved extracts were filtered through the Whatman-1 filter paper and collected and then concentrated at reduced pressure at $50^{\circ} \mathrm{C}$ using a rotary evaporator to obtain crude extracts. $50 \mathrm{~g}$ of the crude extract was then suspended in distilled water and successively partitioned with three different solvents based on their polarity, i.e., n-hexane, followed by dichloromethane and ethyl acetate.

2.4. Total Phenolic and Flavonoid Contents. The TPC of the extracts was determined using the Folin-Ciocalteu reagent, as described previously $[62,63]$ with slight modification. $20 \mu \mathrm{L}$ of each extract $(0.5 \mathrm{mg} / \mathrm{mL})$ was separately mixed with Folin-Ciocalteau's reagent $(100 \mu \mathrm{L}, 1: 10 \mathrm{v} / \mathrm{v}$ diluted with distilled water) and aqueous sodium carbonate $\left(\mathrm{Na}_{2} \mathrm{CO}_{3}\right.$, $80 \mu \mathrm{L}, 1 \mathrm{M}$ ) solution, and then the mixture was allowed to stand for 15 minutes at room temperature. The reaction mixture's absorbance was measured at $765 \mathrm{~nm}$ using a microplate reader (Synergy LX, BioTek, Instruments, Inc., USA). Gallic acid (GA) was used as a standard, and the total polyphenolic concentration in the extracts was expressed as milligrams of gallic acid equivalent per gram of dry weight (mg GAE/g) of the extract. The assay was performed in triplicate.

The TFC of the extracts was determined using the colorimetric method described previously $[64,65]$ with slight modification. Briefly, $20 \mu \mathrm{L}$ of each extract $(0.5 \mathrm{mg} /$ $\mathrm{mL}$ ) was separately mixed with $60 \mu \mathrm{L}$ ethanol and $5 \mu \mathrm{L}$ aluminium trichloride $\left(\mathrm{AlCl}_{3}, 10 \%\right)$. Subsequently, $5 \mu \mathrm{L}$ of $1 \mathrm{M}$ potassium acetate and $110 \mu \mathrm{L}$ distilled water were added to each well, and the reaction mixture was allowed to stand for 30 minutes. The absorbance was then measured at $415 \mathrm{~nm}$ with a microplate reader against blank. Quercetin was used as standard, and the total flavonoid concentration in the extracts was expressed as milligrams of quercetin equivalent per gram of dry weight (mg QE/g) of extract. For each extract, triplicates of measurements were performed.

2.5. Free Radical Scavenging Activity. The free radical scavenging activity was determined using 2,2-diphenyl1-picrylhydrazyl (DPPH), as described previously [66]. Briefly, $0.1 \mathrm{mM}$ solution of DPPH in methanol was prepared, and an equal volume $(100 \mu \mathrm{L})$ of this solution was added to an equal volume of plant samples $(100 \mu \mathrm{L})$ prepared in $30 \%$ DMSO at $0.98-500 \mu \mathrm{g} / \mathrm{mL}$ concentrations. It was incubated 
TABLE 1: List of medicinal plants selected for the study and their ethnopharmacological applications.

\begin{tabular}{lccc}
\hline Scientific name & Family & $\begin{array}{c}\text { Voucher } \\
\text { specimen }\end{array}$ & \multicolumn{1}{c}{ Indigenous uses } \\
\hline A. catechu (L.F.) & Fabaceae & TUCH- & $\begin{array}{c}\text { It is used for anticancer purposes. It is } \\
\text { aseful in cold and cough, ulcers, boils, } \\
\text { antipyretic, acute, and chronic wound } \\
\text { healing [20-23]. Catechin and taxifolin } \\
\text { possess antifungal, antiviral, }\end{array}$ \\
201011 & & $\begin{array}{c}\text { antibacterial, anti-inflammatory, and } \\
\text { antioxidant activity [22]. }\end{array}$
\end{tabular}

4-Hydroxybenzoic acid, kaempferol, quercetin, 3,4',7-trihydroxyl-3',5-

dimethoxyflavone, catechin, epicatechin, afzelechin, epiafzelechin, mesquitol, ophioglonin, aromadendrin, phenol [23]; rhamnetin, 4-hydroxyphenol, 3,3',5, $5^{\prime}, 7-$ pentahydroxyflavane, fisetinidol, 5hydroxy-2-[2-(4-hydroxyphenyl)acetyl]3-methoxybenzoic acid, $n(2 \mathrm{~s}, 3 \mathrm{~S})$ -

$3,7,8,3^{\prime}, 4^{\prime}$-pentahydroxyflavane [24]; rutin

[25]; taxifolin [26]; quercetin 3-methyl ether, caryatin, ellagic acid [27];

robinetinidol [28]; gallochin, gossypetin, phlobatannin, quercitin [29]

Naphthyl-1,3-diol-1-(3 $\beta$-lanost-5,24-

dienyl)-3-n-octadec- 9,12,15-trienoate, naphthyl-1,3-diol-1-(3 $\beta$-lanostan-19-oic acid-yl)-3-n-octadec-9,12-dienoate,

triterpenic ester lanostan-19-oic acid-3 $\beta$ olyl-n-octadec-9,12,15-trienoate,

$\beta$-sitosteryl oleate, $\beta$-sitosterol glucoside

[41]; lupenol, $\gamma$-sitosterol, 1,2-Benzenediol [42]; phenol, salicylaldehyde,

Bark is used in diarrhoea, dysentery, anti-inflammatory, antibacterial, cooling, astringent, gonorrhoea, and burns [30, 31]. Leaves are used in hiccups, vomiting, cooling, gonorrhoea, asthma, cough, diarrhoea, and gastric problems. Similarly, fruits are used in

$\begin{array}{lll}\text { F. religiosa } & \text { Moraceae } & \text { TUCH- } \\ & & 201014\end{array}$
fever, tuberculosis, paralysis, asthma, and digestion [31-33]. It is used for anticancer activity [34], antioxidant, wound healing and anti- inflammatory activity [35], antidiabetic activity [36], and antiamnesic activity [37]. Lupeol possesses anti-inflammatory activity

[38]. Quercetin and kaempferol possess antifungal property $[39,40]$. phenylacetaldehyde, allyl caproate, linalool, n-nonanal, adipoin, methylcyclopentane, 2-dione, itaconic anhydride, 2-phenylethyl alcohol,

benzeneacetonitrile, nonadienal, nonen-1ol, nonadienol, linalool oxide, catechol, coumaran, cinnamyl alcohol,

vinylguaiacol, hexenyl tiglate, eugenol, hexenyl hexenoate, $\beta$-ionone,

dihydroactinidiolide, $\alpha$-copaene, hexenyl benzoate, eudesmol, eudesmol, epi$\alpha$-cadinol, $\beta$-eudesmol, $\alpha$-eudesmol, $\alpha$-cadinol, pentadecanal, palmitic acid and itaconic anhydride, 3-methylcyclopentane1, 2-dione [43]; undecane, tridecane, tetradecane, (e)- $\beta$-ocimene $\beta$-bourbonene, $\beta$-caryophyllene, $\alpha$-trans bergamotene, $\alpha$-thujene, $\alpha$-pinene, $\beta$-pinene, $\alpha$-terpinene, limonene, dendrolasine, dendrolasine $\alpha$-ylangene, $\alpha$-copaene, aromadendrene, $\alpha$-humulene,

alloaromadendrene, germacrene, bicyclegermacrene, $\gamma$-cadinene and $\delta$-cadinene $[44,45]$ 
TABLE 1: Continued.

\begin{tabular}{|c|c|c|c|c|}
\hline Scientific name & Family & $\begin{array}{l}\text { Voucher } \\
\text { specimen }\end{array}$ & Indigenous uses & Chemical constituents \\
\hline M. melabathrium & Melastomataceae & $\begin{array}{l}\text { TUCH- } \\
201013\end{array}$ & $\begin{array}{l}\text { It is used in looseness of the bowels, the } \\
\text { runs, hemorrhoids, leucorrhoea, wounds } \\
\text { and cut lightening urinary issues, } \\
\text { leucorrhea, urinary tract, and toothache } \\
\text { [46, 47]; antiviral activity, cytotoxicity } \\
\text { activity [48], wound healing activity [49], } \\
\text { antiulcer activity, antivenom activity } \\
\text { [50], antidiabetic activity, antioxidant } \\
\text { activity, antihyperlipidemic activity [47]. } \\
\beta \text {-Sitosterol has shown antidiabetic } \\
\text { activity [51]. Betulinic acid, quercetin, } \\
\text { quercitrin, } \alpha \text {-amyrin show anti- } \\
\text { inflammatory activity [52]. }\end{array}$ & $\begin{array}{c}\beta \text {-Sitosterol, } \beta \text {-sitosterol-3-O- } \beta \text {-D- } \\
\text { glucopyranoside, ursolic acid, asiatic acid, } \\
\text { 2-hydroxyursolic acid, Kaempferol [53]; } \\
\alpha \text {-amyrin, betulinic acid, kaempferol-3-O- } \\
\beta \text {-D-glucoside [54]; } 2 \alpha \text {-hydroxyursolic } \\
\text { acid, } \beta \text {-sitosterol 3-O- } \beta \text {-D- } \\
\text { glucopyranoside, } 1,2 \text {-dilinolenyl-3-O- } \beta \text {-D- } \\
\text { galactopyanoside, kaempferol, kaempferol } \\
\text { 3-O- } \alpha \text { - } L \text {-rhamnopyranoside, kaempferol } \\
\text { 3-O- } \beta \text { - } D \text {-glucopyranoside, kaempferol 3- } \\
O \text { - } \beta \text { - } D \text {-galactopyranoside, kaempferol 3- } \\
\text { O- }\left(2^{\prime \prime}, 6^{\prime \prime} \text {-di-O-E-p-coumaryl)- } \beta \text {-D- }\right. \\
\text { galactopyranoside, quercetin, ellagic acid } \\
\text { [55]; gallic acid, benzoic acid, epicatechin, } \\
\text { malabathrin, casuarictin [56] }\end{array}$ \\
\hline S. robusta gaertn & Dipterocarpaceae & $\begin{array}{l}\text { TUCH- } \\
201010\end{array}$ & $\begin{array}{l}\text { It is used in the treatment of ulcer, } \\
\text { cough, itching, leprosy, and as } \\
\text { anthelmintic [57]. Antibacterial wound } \\
\text { healing and anti-inflammatory activity } \\
\text { due to the presence of polyphenols, } \\
\text { flavonoids, and triterpenoids, etc. } \\
\text { Ursolic acid, amyrin extracted from this } \\
\text { plant is responsible for showing } \\
\text { antibacterial activity and antiulcer [58]. }\end{array}$ & $\begin{array}{c}\text { Ammarenolic acid, asiatic acid [59]; ursolic } \\
\text { acid, tri and tetrahydroxy ursenoic acid, } \alpha \\
\text { and } \beta \text {-amyrin, } \alpha \text {-amyrenone, } \\
\text { mangiferonic acid, benthamic acid and } \\
\text { uvaol [58]; bergenin [60]; caryophyllene } \\
\text { oxide, calarene epoxide, lupeol, } \\
\beta \text {-humulene, } \alpha \text {-amyrin, } \beta \text {-caryophyllene } \\
\text { [61] }\end{array}$ \\
\hline
\end{tabular}

in the dark for 30 minutes, and then the absorbance was measured at $517 \mathrm{~nm}$. A $100 \mu \mathrm{L}$ of $0.1 \mathrm{mM}$ DPPH mixed with $100 \mu \mathrm{L}$ of $30 \%$ DMSO (solvent) was used as control. Quercetin was used as the standard reference compound for this assay. The degree of color change from purple (DPPH radical) to yellow (diphenyl picrylhydrazine) obtained after reduction at different concentrations was measured. The capability to scavenge the DPPH radical was calculated by using the following equation:

$$
\% \text { scavenging }=\frac{A_{o}-A_{t}}{A_{o}} \times 100,
$$

where $A o$ is the absorbance of DPPH with $30 \%$ DMSO and $A_{t}$ is the absorbance of DPPH with a test or reference sample.

\subsection{In Vitro $\alpha$-Glucosidase and $\alpha$-Amylase Inhibition Assays.} The crude extracts for $\alpha$-glucosidase enzyme inhibitory activity were determined by the method described by Fouotsa et al. with slight modification [67]. The $\alpha$-glucosidase (0.2 units) was premixed with $500 \mu \mathrm{g} / \mathrm{mL}$ of extract in $100 \mathrm{mM}$ phosphate buffer saline ( $\mathrm{pH}$ 6.8). Then, $0.7 \mathrm{mM}$ pNPG in the PBS (phosphate buffer saline) buffer was added as a substrate. This reaction mixture was pre-incubated in a 96 -well microplate at $37^{\circ} \mathrm{C}$ for $15 \mathrm{~min}$. The $\alpha$-glucosidase activity was determined by measuring the p-nitrophenol release from the hydrolysis of pNPG at $405 \mathrm{~nm}$ in a microplate with Gene 5 software. Acarbose was used as the standard compound for this assay. The $\%$ $\alpha$-glucosidase inhibitory activity was calculated as given in

$$
\% \text { inhibition }=\frac{A_{o}-A_{t}}{A_{o}} \times 100,
$$

where $A_{o}$ is the absorbance of enzyme-substrate reaction with $30 \%$ DMSO and $A_{t}$ is the absorbance of enzymesubstrate with plant extract.

$\alpha$-Amylase inhibition assay was carried out as described in our previous study [68]. Briefly, $20 \mu \mathrm{L}$ of plant extracts and $80 \mu \mathrm{L}$ of porcine pancreas $\alpha$-amylase $(1.5 \mathrm{U} / \mathrm{mL})$ in phosphate buffer of $\mathrm{pH} 7.0$ were loaded in microplate wells, and initial absorbance was taken. The plate was incubated at $37^{\circ} \mathrm{C}$ for 15 minutes. Then, $100 \mu \mathrm{L}$ of a substrate $(0.5 \mathrm{mM})$, CNPG3 (in the same buffer), was added to start the reaction with incubation for 15 minutes, and change in absorbance was monitored at $405 \mathrm{~nm}$ [68]. The DMSO was taken as control. All the experiments were performed in triplicate in a final volume of $200 \mu \mathrm{L}$ by using a microplate reader. The $\%$ $\alpha$-amylase inhibitory activity was calculated using equation (2), mentioned earlier.

2.7. Antimicrobial Assay of Plant Extracts. Antimicrobial assay of extracts was performed by the agar well diffusion method in Mueller Hinton Agar (MHA) plates [69]. The test organisms were inoculated in Muller Hinton Broth $(\mathrm{MHB})$ and incubated at $37^{\circ} \mathrm{C}$ to adjust the turbidity to 0.5 McFarland standards giving a final inoculum of $1.5 \times 10^{8} \mathrm{CFU} / \mathrm{mL}$. The MHA plates were lawn-cultured with the above maintained microbial inoculum. Plant extracts of $50 \mathrm{mg} / \mathrm{mL}$ concentration were prepared in $50 \%$ DMSO. Six wells of $6 \mathrm{~mm}$ were bored in the cultured lawn 
media with the help of a sterile cork-borer $(6 \mathrm{~mm})$. Each well was filled with $50 \mu \mathrm{L}$ plant extract with the positive control (neomycin $50 \mathrm{mg} / \mathrm{mL}$ ) and negative control $(50 \%$ DMSO) in each experiment set. It was allowed to diffuse for about 15 minutes at room temperature and incubated for $18-24$ hours at $37^{\circ} \mathrm{C}$. After incubation, plates were observed to form a clear, i.e., zone of inhibition (ZoI) around the well and measured in $\mathrm{mm}$.

2.8. Determination of MIC and MBC. The broth microdilution method was used to determine the MIC and MBC, according to Clinical and Laboratory Standards Institute (CLSI) [70]. Twofold serial dilutions of extracts were prepared directly in sterile 96-well microdilution plates with flat bottom wells containing $\mathrm{MHB}$ to obtain various concentrations. The bacterial inoculum was added at a final concentration of $10^{6} \mathrm{CFU} / \mathrm{mL}$ by diluting $1: 100$ the $0.5 \mathrm{McF}$ arland turbidity culture in MHB. Finally, five $\mu \mathrm{L}$ of bacteria was added to each well except for negative control.

Neomycin is a standard drug that was used as a positive control. The plate was covered with a sterile lid and incubated for $24 \mathrm{~h}$ at $37^{\circ} \mathrm{C}$. Resazurin $(0.003 \%)$ was added to each well of the microtiter plate and was incubated at $37^{\circ} \mathrm{C}$ for 3-4 hrs. The wells containing the bacterial growth turned into pink color, whereas the well without bacterial growth remained blue. The MIC was considered as the lowest concentration of the extract that completely inhibits bacterial growth. The MBC was determined by streaking the content of wells onto NA plates with incubation of over 18 hours at $37^{\circ} \mathrm{C}[70]$.

2.9. Molecular Annotation. Plant fractions were subjected to LC-HRMS. Identification of metabolites from an active fraction of water and ethyl-acetate extract of $A$. catechu, ethyl acetate fraction of $S$. robusta, ethyl acetate fraction of M. melabathrium, and hexane fraction of F. religiosa was carried out at Sophisticated Analytical Instrument Facility (SAIF), CSIR-Central Drug Research Institute, Lucknow. Samples were analyzed on an Agilent 6520, AccurateMass Q-TOF Mass Spectrometer equipped with a G1311A quaternary pump, G1329A autosampler, and G1315D diode array detector (DAD). The solvent system consists of acetonitrile $(\mathrm{ACN})$ and $5 \mathrm{mM}$ acetate buffer and water at the flow rate of $0.5 \mathrm{ml} / \mathrm{min}$. The initial condition started from $5 \% \mathrm{ACN}$ for $0.1 \mathrm{~min}$ to $30 \% \mathrm{ACN}$ for $6 \mathrm{~min}, 80 \%$ ACN for $20 \mathrm{~min}$, and back to its initial conditions. During the whole process, column temperature was maintained at $30^{\circ} \mathrm{C}$. After passing through the DAD flow cell, the column elute was directed to Q-TOF HRMS fitted with an electrospray interface (ESI). The MS analysis was carried out using an ESI-positive ionization mode with mass ranges from 100-3000 Da. Raw data obtained from the LC/HRMS system were converted to mzML format using the ProteoWizard tool MSConvertGUI [71]. MZmine 2 was used for peak detection, peak alignment, and identification (target compound annotation) using centroid data [71-73].
2.10. Data Analysis. The results were processed by using Gen5 Microplate Data Collection and Analysis Software and then by MS Excel. The $\mathrm{IC}_{50}$ (inhibition of enzymatic hydrolysis of the substrate pNPG and CNPG3 by 50\%) value was calculated using the Graphpad Prism software version 8. Values were expressed as a mean \pm standard error of the mean of triplicate. The LC-HRMS metabolic was processed in an untargeted manner with MZmine 2 and used MestreNova 12.0 tool to annotate the molecules. The metabolites were searched using the Pubchem database, and Dictionary of Natural Products 2.

\section{Results and Discussion}

3.1. Total Phenolic and Flavonoid Contents. The TPC and TFC were expressed as the GAE/g, and QE/g of extract using a calibration curve of gallic acid and quercetin, respectively. The TPC of plant extracts follows the order A. catechu $>S$. robusta $>M$. malabathricum $>$ F. religiosa. Likewise, the TFC of plant extracts follows the order S. robusta $>$ M. malabathricum $>$ F. religiosa $>A$. catechu, which are shown in Table $1 S$.

3.2. Free Radical Scavenging Activity. In this study, the antioxidant activities of crude extracts of plants are shown in Table 2S. DPPH radical scavenging results were reported as $\mathrm{IC}_{50}$ and compared with the $\mathrm{IC}_{50}$ value of quercetin $(6.3 \pm 1.0 \mu \mathrm{g} / \mathrm{mL})$ as a standard. The radical scavenging ability of plant extracts follows the order $F$. religiosa $(67.4 \pm 0.6 \mu \mathrm{g} / \mathrm{mL})>M$. malabathricum $(74.9 \pm 5.6 \mu \mathrm{g} / \mathrm{mL})$ $>$ A. catechu $(84.9 \pm 1.9 \mu \mathrm{g} / \mathrm{mL})>$ S. robusta $(111.4 \pm 1.1 \mu \mathrm{g} /$ $\mathrm{mL}$ ). The antioxidant ability is shown by providing hydrogen or electrons from the phytochemicals within extracts to free radicals.

3.3. $\alpha$-Glucosidase Inhibitory Activity. The results of $\alpha$-glucosidase inhibitory activity of the extracts are given in $\mathrm{Ta}$ ble 2. Among the tested fraction, ethyl acetate and water fraction showed the most potent activity with an $\mathrm{IC}_{50}$ value ranging within $9-114.9 \mu \mathrm{g} / \mathrm{mL}$ against the $\alpha$-glucosidase enzyme as compared to acarbose $\left(\mathrm{IC}_{50}=344.23 \pm 1.03 \mu \mathrm{g} /\right.$ $\mathrm{mL})$. The ethyl acetate fraction of plants understudy on $\alpha$-glucosidase inhibitory activity follows the order as M. malabathricum $>S$. robusta $>F$. religiosa $>A$. catechu while that of aqueous fraction follows A. catechu $>$ M. malabathricum $>$ S. robusta $>$ F. religiosa.

3.4. $\alpha$-Amylase Inhibitory Activity. In the $\alpha$-amylase assays (Table 2), crude methanol extracts and their ethyl acetate fractions effectively inhibited the enzyme activity compared to other fractions. Crude extracts of F. religiosa followed by that of S. robusta and A. catechu showed antidiabetic activity with an $\mathrm{IC}_{50}$ of $29.24 \pm 1.173,89.127 \pm 0.758$, and $115 \pm 4.004 \mu \mathrm{g} / \mathrm{mL}$, respectively, compared to acarbose $\left(\mathrm{IC}_{50}=6.1 \pm 0.1 \mu \mathrm{g} / \mathrm{mL}\right)$. The hexane fraction of $F$. religiosa bark extract inhibited $\alpha$-amylase with $\mathrm{IC}_{50}$ of 
TABLE 2: $\alpha$-Glucosidase and $\alpha$-amylase inhibitory activity and $\mathrm{IC}_{50}(\mu \mathrm{g} / \mathrm{mL})$ values of various fractions.

\begin{tabular}{lcccccccccc}
\hline \multirow{2}{*}{ Plants } & \multicolumn{2}{c}{ Crude extract } & \multicolumn{2}{c}{ Hexane fraction } & \multicolumn{2}{c}{ DCM fraction } & \multicolumn{2}{c}{ Ethyl acetate fraction } & \multicolumn{2}{c}{ Water fraction } \\
& $\mathrm{G}$ & $\mathrm{A}$ & $\mathrm{G}$ & $\mathrm{A}$ & $\mathrm{G}$ & $\mathrm{A}$ & $\mathrm{G}$ & $\mathrm{A}$ & $\mathrm{G}$ & $\mathrm{A}$ \\
\hline A. catechu & $23.7 \pm 0.7$ & $115 \pm 4.0$ & $<50 \%$ & $<50 \%$ & $75.1 \pm 3.6$ & $<50 \%$ & $57.6 \pm 1.9$ & $<50 \%$ & $9.0 \pm 0.6$ & $73.2 \pm 4.3$ \\
F. religiosa & $28.5 \pm 0.7$ & $29.2 \pm 1.2$ & $18.2 \pm 0.2$ & $70.2 \pm 5.8$ & $<50 \%$ & $<50 \%$ & $24.7 \pm 0.1$ & $78.93 \pm 1.1$ & $114.9 \pm 2.7$ & $<50 \%$ \\
M. malabathricum & $82.6 \pm 3.0$ & $221.2 \pm 1.9$ & $<50 \%$ & $<50 \%$ & $<50 \%$ & $<50 \%$ & $9.1 \pm 0.3$ & $213.5 \pm 2.4$ & $11.6 \pm 0.6$ & $<50 \%$ \\
S. robusta & $34.8 \pm 0.7$ & $89.1 \pm 0.8$ & $188.5 \pm 2.4$ & $<50 \%$ & $200.8 \pm 4.6$ & $<50 \%$ & $21.4 \pm 0.5$ & $69.3 \pm 1.1$ & $50.9 \pm 1.5$ & $<50 \%$ \\
\hline
\end{tabular}

G: $\alpha$-glucosidase and A: $\alpha$-amylase.

$68.234 \pm 5.812 \mu \mathrm{g} / \mathrm{mL}$. Only the aqueous fraction of A. catechu was significant towards $\alpha$-amylase.

3.5. Antimicrobial Activity. Antimicrobial activity of different fractions of plants was tested against ATCC strains such as Staphylococcus aureus ATCC 43300, Escherichia coli ATCC 2591, Klebsiella pneumoniae ATCC 700603, Salmonella typhi ATCC 14028, and Shigella sonnei ATCC 25931. The ZoI of each fraction of plants is shown in Table 3. The representative pictures showing $\mathrm{ZoI}$ of $A$. catechu extract against S. aureus ATCC 43300 and E. coli ATCC 2591 are shown in Figure 1S.

3.6. Minimum Inhibitory and Bactericidal Concentration. Different fractions were examined for MIC and MBC against five ATCC strains such as S. aureus ATCC 43300, E. coli ATCC 25931, K. pneumonia ATCC 700603, S. typhi ATCC 14028, and S. sonnei ATCC 25931. The MIC of different fractions against ATCC reference strains was found between $0.3 \mathrm{mg} / \mathrm{mL}$ and $25 \mathrm{mg} / \mathrm{mL}$ shown in Table 4. M. malabathricum and $S$. robusta extract showed inhibition at lower concentrations, but it requires more concentration to kill the bacterial growth, as evidence by MIC and MBC values. MIC of water fraction of $A$. catechu and ethyl acetate fraction of F. religiosa against K. pneumonia ATCC 700603 is shown in Figure 2S. Likewise, MBC of ethyl acetate fraction of $A$. catechu and M. malabathricum against $S$. sonnei ATCC 25931 is shown in Figure 3S.

3.7. Molecular Annotation. The raw data of LC-HRMS were processed using MZmine and MestreNova 12.0 tool was used for further analysis. The total ion chromatogram (TIC) of the fractions subjected for LC-HRMS analysis is shown in Figure $4 \mathrm{~S}$. These results were verified with available public compound databases. Compounds were annotated from the fractions of all 4 plants. The annotated molecules from our spectra are catechin (Figure 5S), epicatechin (Figure 5S), gallocatechin (Figure 6S), epigallocatechin (Figure 6S), procyanidin (Figure 7S), emodin (Figure 8S), quercetin (Figure 9S), gossypin (Figure 10S), bergenin (Figure 11S), quercetin 3- O- $\beta$ D-apiofuranosyl(1 $\longrightarrow$ 2)-[6-O-(3-hydroxy-3-methylglutaroyl )]- $\beta$-D-glucopyranoside (Figure 12S), quercetin 7-methyl ether 3-[3-hydroxy-3-methylglutaryl-(1->6)]-[apiosyl-(1->2)-galacto side] (Figure 13S), avicularin (quercetin 3- $\alpha$-L-arabinofuranoside) (Figure 14S), kaempferol 3-O- $\alpha$-L-arabinopyranoside (Figure 15S), quercetin 3-O-(6"-O-galloyl)- $\beta$-glucopyranoside (Figure 16S), kaempferol (Figure 17S), isoquercetin
(Figure 18S), and dorsteniol (Figure 19S) which are shown in Table 5 (Figure 1).

\section{Discussion}

Plants synthesize a wide range of secondary metabolites which showed broad-spectrum enzyme inhibitory potential. Nepal is a Himalayan nation with lopsidedly rich flora and fauna located at a transition zone between the flora of the Western Himalaya and the Eastern Himalaya [74]. The assorted variety of species in Nepalese flora offers incredible open doors for the hunt of medicinal substances. Nepal has been underexplored in terms of medicinal plants. Due to poor infrastructures and funding in research, most of the analytics have not been explored out of its biodiverse flora and fauna. Though there are some works in the past, most of them are restricted only up to the crude activity. No research group has gone so far as to annotate compounds from Nepalese plants. Khadayat et al. studied the $\alpha$-amylase inhibitory activity of Nepalese medicinal plants up to crude extract. Aryal et al. and Phuyal et.al. studied only TPC, TFC, and antioxidant potential of plants available in Nepal $[68,75,76]$; Sai et al. and Subba et al. studied phytochemical screening, antioxidant and $\alpha$-amylase inhibitory activities of medicinal plants from Nepal $[77,78]$. Since natural products have contributed $48.64 \%$ as a source of new drugs for diabetes [79], we aim to annotate secondary metabolites from Nepalese plants covered by multiple pharmacological applications based on previous experiments.

Compounds like quercetin, ferulic acid, anthocyanins, catechin, and resveratrol, which are plant-based phenolics and flavonoids, are responsible for regulating glycemia through insulin secretion, increased glucose uptake, lipid peroxidation inhibition, and inhibition of enzymes like $\alpha$-glucosidase, and $\alpha$-amylase [80,81]. Due to the vast health benefits such as antioxidant, antimicrobial, antiulcer, antidiabetic, hepatoprotective, and anticarcinogenic activities of phenolic and flavonoid compounds, thus they are considered as a major class of phytochemicals $[82,83]$.

Previously, evidence of antidiabetic activity of M. malabathricum leaves extract has been shown by in vivo experiments on diabetes-induced rats $[47,84]$ to support our results. A. catechu (L.f.) Willd. leaf extracts showed an $\mathrm{IC}_{50}$ of $0.4977 \mathrm{mg} / \mathrm{mL}$ against $\alpha$-glucosidase [85]. Similarly, kaempferol, quercetin, naringenin, and baicalein were the flavonoids isolated from $F$. racemosa stem bark showing a significant decrease in blood glucose levels in diabetes-induced albino Wistar rats [86]. Additionally, gossypetin, herbacetin, kaempferol, leucoperalgonidin, 
TABLE 3: Zone of inhibition $(\mathrm{mm})$ of each fraction of plants.

\begin{tabular}{|c|c|c|c|c|c|c|c|c|c|c|c|c|c|c|c|c|c|}
\hline & \multicolumn{4}{|c|}{$\begin{array}{l}\text { Acacia catechu } \\
\quad \text { (fraction) }\end{array}$} & \multicolumn{4}{|c|}{$\begin{array}{l}\text { Shorea robusta } \\
\quad \text { (fraction) }\end{array}$} & \multicolumn{4}{|c|}{$\begin{array}{l}\text { Melastoma } \\
\text { malabathricum } \\
\text { (fraction) }\end{array}$} & \multicolumn{4}{|c|}{ Ficus religiosa (fraction) } & \multirow[t]{2}{*}{$\mathrm{PC}$} \\
\hline & $\mathrm{H}$ & $\mathrm{D}$ & $\mathrm{E}$ & $\mathrm{W}$ & $\mathrm{H}$ & $\mathrm{D}$ & $\mathrm{E}$ & $\mathrm{W}$ & $\mathrm{H}$ & $\mathrm{D}$ & $\mathrm{E}$ & $\mathrm{W}$ & $\mathrm{H}$ & $\mathrm{D}$ & $\mathrm{E}$ & $\mathrm{W}$ & \\
\hline S. aureus & 10 & 9 & 12 & 14 & 9 & - & - & - & 10 & - & - & - & 10 & - & - & - & 10 \\
\hline E. coli & - & - & - & - & - & - & - & - & - & - & - & - & - & - & 7 & - & 16 \\
\hline K. pneumoniae & 9 & 6 & 10 & 13 & - & 7 & - & 8 & - & - & - & - & 8 & - & 10 & 8 & 19 \\
\hline S. typhi & - & - & - & - & - & - & - & - & - & - & - & - & - & - & - & - & 18 \\
\hline S. soni & 6 & 9 & 11 & 10 & - & 8 & 14 & 15 & - & 8 & 16 & 15 & 7 & - & 10 & - & 25 \\
\hline
\end{tabular}

H: hexane; D: DCM; E: ethyl acetate; W: water; PC: positive control (neomycin).

TABle 4: Minimum inhibitory concentrations and minimum bactericidal concentrations (mg/mL) of different fractions against microorganisms.

\begin{tabular}{lcccccccccc}
\hline & \multicolumn{2}{c}{ Acacia cathecu } & \multicolumn{2}{c}{ Shorea robusta } & \multicolumn{2}{c}{$\begin{array}{c}\text { Melostoma } \\
\text { malabathricum }\end{array}$} & \multicolumn{2}{c}{ Ficus religiosa } & \multicolumn{2}{c}{ Positive control } \\
& MIC & MBC & MIC & MBC & MIC & MBC & MIC & MBC & MIC & MBC \\
\hline S. aureus & 3.1 & 25 & 0.3 & 6.25 & 3.1 & 25 & 3.1 & 12.5 & 0.062 & 0.25 \\
E. coli & - & - & - & - & - & - & 12.5 & 50 & 0.004 & 0.008 \\
K. pneumoniae & 12.5 & 25 & - & - & - & - & 6.25 & 25 & 0.004 & 0.008 \\
S. typhi & - & - & - & - & - & - & & 0.004 & 0.03 \\
S. sonnei & 6.25 & 12.5 & 6.25 & 25 & 1.56 & 25 & 3.12 & 12.5 & 0.002 & 0.06 \\
\hline
\end{tabular}

TABLE 5: Secondary metabolites from the different fractions of plants.

\begin{tabular}{|c|c|c|c|c|c|c|c|}
\hline Annotated compounds & $\begin{array}{l}\text { Calculated } \\
\text { Mass }\end{array}$ & $\begin{array}{c}\text { Observed } \\
\text { Mass }\end{array}$ & Formula & $\begin{array}{c}\text { Double bond } \\
\text { equivalence }\end{array}$ & $\begin{array}{l}\text { Absolute } \\
\text { error } \\
(\mathrm{ppm})\end{array}$ & $\begin{array}{c}\text { Retention } \\
\text { time }\left(t_{\mathrm{R}}\right) \\
\text { minute } \\
\end{array}$ & Source \\
\hline Catechin or epicatechin & 290.07 & 291.08 & $\mathrm{C}_{15} \mathrm{H}_{14} \mathrm{O}_{6}$ & 9 & 0.16 & 6.25 & A. catechu (W and E) \\
\hline $\begin{array}{l}\text { Gallocatechin or } \\
\text { epigallocatechin }\end{array}$ & 306.07 & 307.08 & $\mathrm{C}_{15} \mathrm{H}_{14} \mathrm{O}_{7}$ & 9 & 0.65 & 5.22 & A. catechu (W and $\mathrm{E})$ \\
\hline Procyanidin & 578.15 & 579.15 & $\mathrm{C}_{30} \mathrm{H}_{26} \mathrm{O}_{12}$ & 18 & 0.79 & 5.87 & A. catechu (W and $\mathrm{E}$ ) \\
\hline Emodin & 270.05 & 271.06 & $\mathrm{C}_{15} \mathrm{H}_{10} \mathrm{O}_{5}$ & 11 & 2.8 & 18.65 & A. catechu (E) \\
\hline Quercetin & 302.04 & 303.05 & $\mathrm{C}_{15} \mathrm{H}_{10} \mathrm{O}_{7}$ & 11 & 3.65 & 8.04 & $\begin{array}{l}\text { S. robusta/A. catechu/ } \\
\text { M. malabathricum (E) }\end{array}$ \\
\hline Gossypin & 480.09 & 481.09 & $\mathrm{C}_{21} \mathrm{H}_{20} \mathrm{O}_{13}$ & 12 & 1.84 & 8.8 & S. robusta $(\mathrm{E})$ \\
\hline Bergenin & 328.08 & 329.08 & $\mathrm{C}_{14} \mathrm{H}_{16} \mathrm{O}_{9}$ & 7 & 2.91 & 5.11 & S. robusta $(\mathrm{E})$ \\
\hline $\begin{array}{l}\text { Quercetin 3-O- } \beta \text {-D- } \\
\text { apiofuranosyl }(1 \longrightarrow 2)-[6-\mathrm{O}-(3- \\
\text { hydroxy-3-methylglutaroyl)]- } \\
\beta \text {-D-glucopyranoside }\end{array}$ & 740.18 & 741.18 & $\mathrm{C}_{32} \mathrm{H}_{36} \mathrm{O}_{20}$ & 15 & 4.31 & 11.52 & S. robusta $(\mathrm{E})$ \\
\hline $\begin{array}{l}\text { Quercetin 7-methyl ether 3-[3- } \\
\text { hydroxy-3-methylglutaryl-(1- } \\
>6)] \text {-[apiosyl-(1->2)- } \\
\text { galactoside] }\end{array}$ & 754.19 & 755.19 & $\mathrm{C}_{33} \mathrm{H}_{38} \mathrm{O}_{20}$ & 15 & - & 12.76 & S. robusta $(\mathrm{E})$ \\
\hline $\begin{array}{l}\text { Avicularin (quercetin 3- } \alpha-\mathrm{L}- \\
\text { arabinofuranoside) }\end{array}$ & 435.09 & 434.08 & $\mathrm{C}_{20} \mathrm{H}_{18} \mathrm{O}_{11}$ & 12 & 3.9 & 7.83 & S. robusta $(\mathrm{E})$ \\
\hline $\begin{array}{l}\text { Kaempferol 3-O- } \alpha \text {-L- } \\
\text { arabinopyranoside }\end{array}$ & 418.08 & 419.08 & $\mathrm{C}_{20} \mathrm{H}_{18} \mathrm{O}_{10}$ & 12 & 2.83 & 8.22 & S. robusta $(\mathrm{E})$ \\
\hline $\begin{array}{l}\text { Quercetin 3-O-(6"-O-galloyl)- } \\
\beta \text {-glucopyranoside }\end{array}$ & 616.1 & 617.11 & $\mathrm{C}_{28} \mathrm{H}_{24} \mathrm{O}_{16}$ & 17 & 0.65 & 7.16 & M. malabathricum (E) \\
\hline Kaempferol & 286.04 & 287.05 & $\mathrm{C}_{15} \mathrm{H}_{10} \mathrm{O}_{6}$ & 11 & 0.19 & 8.69 & M. malabathricum (E) \\
\hline Isoquercetin & 464.09 & 465.1 & $\mathrm{C}_{21} \mathrm{H}_{20} \mathrm{O}_{12}$ & 12 & 0.43 & 7.58 & M. malabathricum (E) \\
\hline Dorsteniol & 262.08 & 263.09 & $\mathrm{C}_{14} \mathrm{H}_{14} \mathrm{O}_{5}$ & 8 & 1.19 & 8.14 & F. religosa $(\mathrm{H})$ \\
\hline
\end{tabular}

E: ethyl acetate; W: water; H: hexane. 
<smiles>Oc1cc(O)c2c(c1)O[C@H](c1ccc(O)c(O)c1)[C@@H](O)C2</smiles><smiles>Cc1cc(O)c2c(c1)C(=O)c1cc(O)cc(O)c1C2=O</smiles><smiles>COc1c(O)cc2c(c1O)[C@@]1(C(=O)O)O[C@H](CO)[C@@H](O)[C@H](O)[C@H]1OC2=O</smiles>

Bergenin<smiles>C[C@@](O)(CC(=O)OCCCOC(Oc1c(-c2ccc(O)c(O)c2)oc2cc(O)cc(O)c2c1=O)C(O)CO)CC(O)OC1OCC2(O)COC1C2O</smiles>

Quercetin 3- O-ß-D-apiofuranosyl $(1 \rightarrow 2)$ [6-0-(3-hydroxy-3-methylglutaroyl)]B-D-glucopyranoside<smiles>COc1cc(O)c2c(=O)c(OC3OC(COC(=O)C[C@](C)(O)CC(=O)O)C(O)C(O)C3OC3OCC(O)(CO)C3O)c(-c3ccc(O)c(O)c3)oc2c1</smiles>

Quercetin 7-methyl ether 3-[3-hydroxy3-methylglutaryI-(1->6)]-[apiosyl-

(1->2)-galactoside]<smiles>O=c1c(O[C@@H]2O[C@H](CO)[C@@H](O)[C@H]2O)c(-c2ccc(O)c(O)c2)oc2cc(O)cc(O)c12</smiles><smiles>O=c1c(O)c(-c2ccc(O)cc2)oc2cc(O)cc(O)c12</smiles>
Avicularin

Kaempferol 3-O-B-L-arabinopyranoside<smiles>O=c1c(O)c(-c2ccc(O)cc2)oc2cc(O)cc(O)c12</smiles><smiles>O=c1c(O[C@@H]2O[C@H](CO)[C@@H](O)[C@H](O)[C@H]2O)c(-c2ccc(O)c(O)c2)oc2cc(O)cc(O)c12</smiles>

Quercetin 3-O-(6"-O-galloyl)-ß-glucopyranoside

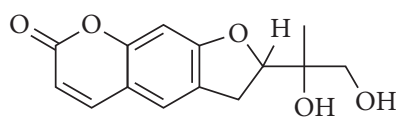

Dorsteniol

Figure 1: Secondary metabolites annotated during the study. 
leucodelphinidin, and sorbifolin from Ficus species were shown as potential digestive enzymes inhibitors through in silico analysis [87].

Phenolic and flavonoid compounds play a major role in free radical scavenging activity via chain termination of free radicals that depend on hydroxyl groups' number and position by donating hydrogen atoms [88]. The structural features like many hydroxyl groups and their configuration, the ketonic functional group at $\mathrm{C}-4$, and a double bond at C2-C3 on flavonoids enhanced the antioxidant ability $[89,90]$. Due to these structural features, extracts with higher phenolic compounds are already proved to have a higher antidiabetic ability via the formation of hydrogen bonds and hydrophobic interactions with enzymes and reduce their activity [91, 92]. There are high correlations between antioxidant capacity and total phenols and total flavonoids, so the presence of a high concentration of phenolic compounds also has high antioxidant activity [75]. There is no correlation between high TPC and TFC value with high antioxidant activity in our study. Bioactive compounds present in plant extracts showed antidiabetic activity by inhibiting glucose absorption in the intestinal tract (inhibiting the different steps of carbohydrates digestion) or antioxidant ability [93].

Phytochemicals such as vitamins (A, C, E, and K), carotenoids, terpenoids, flavonoids, polyphenols, alkaloids, tannins, saponins, pigments, enzymes, and minerals have antimicrobial and antioxidant activity $[13,14]$. The antimicrobial activity of extracts from different parts of A. catechu [22, 94-97], F. religiosa [98], M. malabathricum $[55,99]$, and $S$. robusta [100] has been shown previously. However, the variation in activity is mainly due to diversities in phytochemicals. A. catechu extracts inhibit the growth of Bacillus subtilis, S. aureus, S. typhimurium E. coli, and Pseudomonas aeruginosa with MIC of $1,000 \mu \mathrm{g} / \mathrm{mL}$ against S. aureus and B. subtilis while that for S. typhimurium, E. coli, and $P$. aeruginosa was $700,1,500$, and $\leq 2,000 \mu \mathrm{g} / \mathrm{mL}$, respectively [22]. M. malabathricum has been shown with activity against $S$. aureus, B. subtilis, B. cereus, E. coli, $P$. aeruginosa, S. typhi, and K. pneumonia [55]. Ismail showed extracts from Melastoma species exhibited MIC activity ranges from 12.5 to $100 \mathrm{mg} / \mathrm{mL}$ against $E$. coli, P. Aeruginosa, B. cereus, and S. aureus [101]. Antimicrobial activity of $S$. robusta against $P$. aeruginosa, $S$. aureus, E. coli, E. faecalis, C. albicans, and A. niger showed ZoI of 7-25 mm [100].

Catechin, epicatechin, and taxifolin from $A$. catechu [26, 96]; ursolic acid, $2 \alpha$-hydroxyursolic acid, asiatic acid, $\beta$-sitosterol 3-O- $\beta$-D-glucopyranoside, quercetin, ellagic acid, and kaempferol from M. malabathricum [55]; and amarogentin, amaroswerin, gentianine, mangiferin, oleanolic acid, swechirin, swertiamarin, sweroside, swertanoone, ursolic acid, etc. from S. chirayita [102, 103] were identified with antibacterial ability.

The mechanism behind the antimicrobial activity of phenolic compounds and flavonoids is the inhibition of nucleic acid synthesis, cytoplasmic membrane function, energy metabolism, attachment and biofilm formation, and porin on the cell membrane, and membrane permeability alteration leading to cell destruction as well as attenuation of pathogenicity [104]. In our study, most of the extracts showed higher antibacterial activity against gram-positive bacteria as compared to gram-negative bacteria; it might be due to differences in the cell wall structure as the peptidoglycan layer in gram-positive bacteria is an ineffective permeability barrier as compared to gram-negative bacteria containing outer membrane and a unique periplasmic space rich in lipopolysaccharide molecules, which act as a barrier for the penetration of numerous antimicrobial compounds [105].

The most time-consuming steps are metabolite identification. Because of the time-consuming and the availability of plant materials, we performed LC/HRMS for metabolite profiling based on in vitro assay rather than performing highperformance liquid chromatography (HPLC), LC-HRMS/ MS, and nuclear magnetic resonance (NMR). Likewise, after performing LC-HRMS we proceeded with our raw data with MZmine and overlayed our ion chromatogram. A. catechu may contain catechin or epicatechin: base peak m/z 291.086 (elemental composition $\mathrm{C}_{15} \mathrm{H}_{14} \mathrm{O}_{6} ; \mathrm{t}_{\mathrm{R}} 6.25$ ); fragments peak at 139 and $[\mathrm{M}+\mathrm{Na}]^{+}$peak at $\mathrm{m} / \mathrm{z} 313.2$ comparing our result with Hye et al., Ibrahim et al., Shen et al., and Wang et al., [106-109]. The fragmentation pattern of catechin/epicatechin is shown in Figure 20S. It is predicted to be gallocatechin/ epigallocatechin and procyanidin: in our spectra, we observed $[\mathrm{M}+\mathrm{H}]^{+}$peak m/z $307.08\left(\mathrm{C}_{15} \mathrm{H}_{14} \mathrm{O}_{7} ; t_{\mathrm{R}} 5.22\right)$; fragment peak at $\mathrm{m} / \mathrm{z} 289$ and 139 for gallocatechin/epigallocatechin. The fragmentation pattern of gallocatechin/ epigallocatechin is shown in Figure 21S. Likewise, the molecular ion peak at $\mathrm{m} / \mathrm{z} 579.15\left(\mathrm{C}_{30} \mathrm{H}_{26} \mathrm{O}_{12} ; t_{\mathrm{R}}\right.$ 5.79) with catechin-like RDA fragment $[\mathrm{M}+\mathrm{H}-152]+$ at $\mathrm{m} / \mathrm{z} 427.13$ is speculated as procyanidin similar to the study by Shen et al. [108]. Additionally, the quasimolecular ion peak at $\mathrm{m} / \mathrm{z} 271.06$ $\left(\mathrm{C}_{15} \mathrm{H}_{10} \mathrm{O}_{5} ; t_{\mathrm{R}}\right.$ 18.65) with fragment peak at $\mathrm{m} / \mathrm{z} 253,243,229$, 225 , and 197 is annotated as emodin consistent with the study by Zhan et al. The fragmentation pattern of emodin is shown in Figure 22S.

The absence of myricetin and the presence of proanthocyanidin in the leaves of $S$. robusta were very significant $[111,112]$. Base peak with $\mathrm{m} / \mathrm{z} 303.051\left(\mathrm{C}_{15} \mathrm{H}_{10} \mathrm{O}_{7} ; t_{\mathrm{R}} 8.04\right)$ was expected to be quercetin. The fragmentation pattern of the quercetin is shown in Figure 23S. Similarly, base peak with $\mathrm{m} / \mathrm{z} 481.09\left(\mathrm{C}_{21} \mathrm{H}_{20} \mathrm{O}_{20} ; t_{\mathrm{R}} 6.82\right)$ and the fragment ion at $\mathrm{m} /$ $\mathrm{Z}=319.05$ and 287.15 is interpreted as gossypin comparing our spectra with Giorio et al. and Petsalo et al. [113, 114]. The base peak at $\mathrm{m} / \mathrm{z} 329.08$ (molecular formula $\mathrm{C}_{14} \mathrm{H}_{16} \mathrm{O}_{9} ; t_{\mathrm{R}}$ 5.11) and quasi molecular ion peak $[\mathrm{M}+\mathrm{Na}]^{+}$at $\mathrm{m} / \mathrm{z} 351.06$ are expected to be bergenin isolated from $S$. robusta with reference from the data collected from our spectra and Mukherjee et al. [60]. The other flavonoid is expected to be quercetin 3- O- $\beta$-D-apiofuranosyl( $1 \longrightarrow 2)$-[6-O-(3-hydroxy-3-methylglutaroyl)]- $\beta$-D-glucopyranoside: base peak $\mathrm{m} / \mathrm{z} 741.18\left(\mathrm{C}_{32} \mathrm{H}_{36} \mathrm{O}_{20} ; t_{\mathrm{R}} 11.52\right),[\mathrm{M}+\mathrm{Na}]^{+} \mathrm{m} / \mathrm{z}=763.16$ and

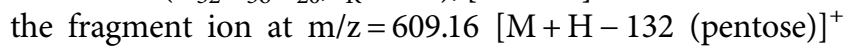
with reference from the data collected from our spectra and Fu et al., 2010 [115]. Adding $14 \mathrm{Da}$ mass on quercetin 3-O$\beta$-D-xylopyranosyl $(1 \longrightarrow 2)$-[6-O-(3-hydroxy-3-methylglutar oyl)]- $\beta$-D-glucopyranoside yields mass equals 755 which could be quercetin 7-methyl ether 3-[3-hydroxy-3- 
methylglutaryl-(1->6)]-[apiosyl-(1->2)-galactoside] [116]. Likewise, the base peak with $\mathrm{m} / \mathrm{z} 435.09\left(\mathrm{C}_{20} \mathrm{H}_{18} \mathrm{O}_{11} ; t_{\mathrm{R}} 7.83\right)$ and fragments peak at $\mathrm{m} / \mathrm{z} 303.05,287.05,183.14$, and 153.02 are predicted to be avicularin (quercetin 3- $\alpha$-L-arabinofuranoside) as spectral figures match with the literature of Santos et al. [117]. Moreover, in our spectra, the base peak with $\mathrm{m} / \mathrm{z} 419.09\left(\mathrm{C}_{20} \mathrm{H}_{18} \mathrm{O}_{10} ; t_{\mathrm{R}} 8.22\right)$ and fragments peak at $\mathrm{m} / \mathrm{z} 287.09([(\mathrm{M}+\mathrm{H})-132])$ are annotated as kaempferol 3$\mathrm{O}-\alpha$-L-arabinopyranoside taking reference of Vuković et al. [118].

M. melabathrium may contain isoquercetin since in our spectra at base peak $\mathrm{m} / \mathrm{z} 465.10\left(t_{\mathrm{R}} 7.58\right)$ and fragments ions at $\mathrm{m} / \mathrm{z} 303.04$ (quercetin) and 289.06 (kaempferol) exactly match with the spectra data of Liu et al. [119]. Base peak at $\mathrm{m} / \mathrm{z} 617.11\left(t_{\mathrm{R}} 7.16\right)$ and fragments ions at $\mathrm{m} / \mathrm{z} 303.05$ corresponding to [aglycone $+\mathrm{H}]^{+}$and at $\mathrm{m} / \mathrm{z} 315.07$ corresponding to [sugar + gallic acid $+\mathrm{H}^{+}$are assumed to be quercetin 3-O-(6"-O-galloyl)- $\beta$-glucopyranoside taking reference of Şöhretoğlu et al. [120]. The other metabolite was reported as kaempferol with base peak $\mathrm{m} / \mathrm{z} 287.05$ $\left(\mathrm{C}_{15} \mathrm{H}_{10} \mathrm{O}_{6} ; t_{\mathrm{R}} 8.69\right)$ and fragments ion at $\mathrm{m} / \mathrm{z} 259.12,165.05$, $153.0,127.03$, and 121.09 respectively. The spectra are similar to March et al. [121]. The fragmentation pattern of kaempferol is shown in Figure 24S. Similarly, from MZmine total ion chromatogram (TIC) we can say that the M. melabathrium and S. robusta may contain quercetin at base peak $\mathrm{m} / \mathrm{z} 303$ as we can observe the peak of quercetin coinciding in both plants.

In hexane fraction of $F$. religiosa, we did defatting by removing the first hexane fraction. But the chromatogram was also seen in our mass spectrometry with fairly fewer amounts. Then, we annotated dorsteniol secondary metabolites in F. religiosa. Literature search shows that Ficus species contain dorsteniol. Our spectra data shows base peak at $\mathrm{m} / \mathrm{z} 263.09\left(\mathrm{C}_{14} \mathrm{H}_{14} \mathrm{O}_{5} ; t_{\mathrm{R}} 8.14\right)$ and $[\mathrm{M}+\mathrm{Na}]^{+}$peak at $\mathrm{m} / \mathrm{z}$ 285.07 as in Alqasoumi et al. [122]. So, the predicted compound is dorsteniol.

In our study, we have annotated 17 secondary metabolites from different plant extract. To support our annotation, more spectroscopic data are required. Crude extracts showed potent activity due to the synergistic effect of compounds. Besides that, ethyl acetate and water fraction showed potent activity; this might be due to phenolic and flavonoid compounds present in those solvents. In some extracts, hexane and DCM showed good inhibition due to terpenes, steroids, and diterpenes present in extracts.

\section{Conclusions}

Due to the rising prevalence of diabetes and antimicrobial resistance, the quest for novel drugs from natural sources persists. The scientific study of different traditional medicinal plants used by diverse groups of people is necessary. Traditional medicinal plants that local peoples have used were screened for antioxidant, antimicrobial, and antidiabetic assay. Among 4 selected medicinal plants from Nepal, most extracts and their fractions can show antioxidant, antimicrobial, and antidiabetic activity, supporting these plants' traditional use. Further works can be carried out on isolation, identification, in silico, and kinetics of potential inhibitors from an active fraction of plant extracts used as a drug candidate for diabetes.

$\begin{array}{ll}\text { Abbreviations } \\ \text { DPPH: } & \text { 2,2-Diphenyl-1-picrylhydrazyl } \\ \text { DM: } & \text { Diabetes mellitus } \\ \text { CNPG3: } & \text { 2-Chloro-4-nitrophenyl- } \alpha \text {-D-maltotrioside } \\ \text { IDF: } & \text { International Diabetes Federation } \\ \text { LC- } & \text { Liquid chromatography-high resolution mass } \\ \text { HRMS: } & \text { spectrometry; } \\ \text { MHB: } & \text { Mueller Hinton Broth } \\ \text { MIC: } & \text { Minimum inhibitory concentration } \\ \text { MBC: } & \text { Minimum bactericidal concentration } \\ \text { PNPG: } & \text { 4-Nitrophenyl- } \alpha \text {-D-glucopyranoside } \\ t_{\mathrm{R}}: & \text { Retention time } \\ \text { ZoI: } & \text { Zone of inhibition } \\ \text { MDR: } & \text { Multidrug resistance } \\ \text { SEA: } & \text { Southeast Asia } \\ \text { CLSI: } & \text { Clinical and laboratory standards institute } \\ \text { TIC: } & \text { Total ion chromatogram. }\end{array}$

\section{Data Availability}

The data used to support the findings of this study are available from the corresponding author upon request.

\section{Disclosure}

This paper has been extracted from an MSc thesis by Babita Aryal and others carried out in Tribhuvan University, Kirtipur, Kathmandu, Nepal.

\section{Conflicts of Interest}

The authors declare no conflicts of interest.

\section{Authors' Contributions}

N.P. designed research; B.A., P.N., K.K., B.A., D.KC., and B.K.S. performed research; B.A., K.K., B.A., N.A., and N.P. analyzed data; and B.A., K.K., B.R.B., and B.A. wrote the paper.

\section{Acknowledgments}

This project was supported by the Higher Education Reform Project (HERP), Tribhuvan University, to Niranjan Parajuli. Grateful acknowledgment is made to the Central Department of Botany, Tribhuvan University, Nepal, for plant identification. The authors are also thankful to the Sophisticated Analytical Instrument Facility (SAIF), CSIRCentral Drug Research Institute, Lucknow, India, for mass analysis.

\section{Supplementary Materials}

Table 1S: Total phenolic and flavonoids content of different plants. Table 2S: Antioxidant ability of plant extracts. Figure 1S: Antimicrobial activity of $A$. catechu extracts 
against S. aureus ATCC 43300 and E. coli ATCC 2591. Figure 2S: MIC of ethyl acetate of $A$. catechu and F. religiosa against S. sonnei ATCC 25931. Figure 3S: MBC of ethyl acetate fraction of $A$. catechu and M. malabathricum against S. sonnei ATCC 25931. Figure 4S: Total ion chromatogram (TIC) of (a) dark blue line: A. catechu ethyl acetate fraction, (b) red line: S. robusta ethyl acetate fraction, (c) green line: A. catechu water fraction, (d) pink line: M. malabathricum ethyl acetate fraction, and (e) sky blue line: F. religiosa hexane fraction. Figure 5S: Mass spectrum of catechin or epicatechin from A. catechu. Figure 6S: Mass spectrum of gallocatechin or epigallocatechin from A. catechu. Figure 7: mass spectrum of procyanidin from $A$. catechu. Figure 8S: Mass spectrum of emodin from $A$. catechu. Figure 9S: mass spectrum of quercetin from S. robusta. Figure 10S: Mass spectrum of gossypin from $S$. robusta. Figure 11S: Mass spectrum of bergenin acid from $S$. robusta. Figure 12S: Mass spectrum of quercetin $3-\mathrm{O}-\beta$-D-apiofuranosyl $(1 \longrightarrow 2)$ [6-O-(3-hydroxy-3-methylglutaroyl)]- $\beta$-D-glucopyranoside from S. robusta. Figure 13S: Mass spectrum of quercetin 7-methyl ether 3-[3-hydroxy-3-methylglutaryl-(1->6)][apiosyl-(1->2)-galactoside] from S. robusta. Figure 14S:Mass spectrum of avicularin (quercetin 3- $\alpha$-L-arabinofuranoside) from S. robusta. Figure 15S: Mass spectrum of kaempferol 3O- $\alpha$-L-arabinopyranoside from $M$. malabathricum. Figure 16S: Mass spectrum of quercetin 3-O-(6"-O-galloyl)$\beta$-glucopyranoside from $M$. malabathricum. Figure 17S: Mass spectrum of kaempferol from M. malabathricum. Figure 18S: Mass spectrum of isoquercetin from M. malabathricum. Figure 19S: Mass spectrum of dorsteniol from F. religiosa. Figure 20S: Fragmentation pattern of catechin/epicatechin. Figure 21S: Fragmentation pattern of gallocatechin/epigallocatechin. Figure 22S: Fragmentation pattern of emodin. Figure 23S: Fragmentation pattern of quercetin derivatives. Figure 24S: Fragmentation pattern of kaempferol. (Supplementary Materials)

\section{References}

[1] N. Balasundram, K. Sundram, and S. Samman, "Phenolic compounds in plants and agri-industrial by-products: antioxidant activity, occurrence, and potential uses," Food Chemistry, vol. 99, no. 1, pp. 191-203, 2006.

[2] A. Zhang, H. Sun, and X. Wang, "Recent advances in natural products from plants for treatment of liver diseases," $E u$ ropean Journal of Medicinal Chemistry, vol. 63, pp. 570-577, 2013.

[3] P. Sheng-Ji, "Ethnobotanical approaches of traditional medicine studies: some experiences from Asia," Pharmaceutical Biology, vol. 39, no. 1, pp. 74-79, 2001.

[4] A. Sharma, R. Verma, and P. Ramteke, "Antibacterial activity of some medicinal plants used by tribals against uti causing pathogens," World Applied Sciences Journal, vol. 7, 2008.

[5] J. Klepacka, E. Gujska, and J. Michalak, "Phenolic compounds as cultivar- and variety-distinguishing factors in some plant products," Plant Foods for Human Nutrition, vol. 66, no. 1, pp. 64-69, 2011.

[6] D. Kalauni and A. Joshi, "Status of medicinal and aromatic plant (maps) and socio-economic influence in Nepalese livelihood-a review research," Acta Scientific Agriculture, vol. 2, pp. 123-130, 2018.
[7] J. L. S. Taylor, T. Rabe, L. J. McGaw, A. K. Jäger, and J. Van Staden, "Towards the scientific validation of traditional medicinal plants," Plant Growth Regulation, vol. 34, no. 1, pp. 23-37, 2001.

[8] IDF, Diabetes Atlas, International Diabetes Federation, Brussels, Belgium, 2019, https://www.diabetesatlas.org/ upload/resources/2019/IDF_Atlas_9th_Edition_2019.html, 9th edition.

[9] E. L. Y. Yam, L. Y. Hsu, E. P.-H. Yap, T. W. Yeo, V. Lee, and J. Schlundt, "Antimicrobial resistance in the Asia Pacific region: a meeting report," Antimicrobial Resistance \& Infection Control, vol. 8, p. 202, 2019.

[10] L. Othman, A. Sleiman, and R. M. Abdel-Massih, "Antimicrobial activity of polyphenols and alkaloids in middle eastern plants," Frontiers in Microbiology, vol. 10, 2019.

[11] E. Middleton, "Biological properties of plant flavonoids: an overview," International Journal of Pharmacognosy, vol. 34, pp. 344-348, 1996.

[12] M. D. E. Biological, "Properties of plant flavonoids: an overview," Pharmaceutical Biology, vol. 34, pp. 344-348, 2008.

[13] G. G. F. Nascimento, J. Locatelli, P. C. Freitas, and G. L. Silva, "Antibacterial activity of plant extracts and phytochemicals on antibiotic-resistant bacteria," Brazilian Journal of Microbiology, vol. 31, pp. 247-256, 2000.

[14] A. A. Shad, S. Ahmad, R. Ullah, N. M. AbdEl-Salam, H. Fouad, and N. U. Rehman, "Phytochemical and biological activities of four wild medicinal plants," Scientific World Journal, vol. 2014, 2014.

[15] G. Siuzdak, An Introduction to Mass Spectrometry Ionization: An Excerpt from the Expanding Role of Mass Spectrometry in Biotechnology, MCC Press, San Diego, CA, USA, 2nd edition, 2005.

[16] M. A. Salem, L. Perez de Souza, A. Serag et al., "Metabolimics in the context of plant natural products research: from sample preparation to metabolite analysis," Metabolites, vol. 10 , no. 1 , p. $37,2020$.

[17] S. Singh and S. K. Verma, "Study of the distribution profile of piperidine alkaloids in various parts of Prosopis juliflora by the application of Direct Analysis in Real Time Mass Spectrometry (DART-MS)," Natural Products and Bioprospecting, vol. 2, no. 5, pp. 206-209, 2012.

[18] M. Petrović, M. D. Hernando, M. S. Díaz-Cruz, and D. Barceló, "Liquid chromatography-tandem mass spectrometry for the analysis of pharmaceutical residues in environmental samples: a review," Journal of Chromatography A, vol. 1067, pp. 1-14, 2005.

[19] S. Banerjee and S. Mazumdar, "Electrospray ionization mass spectrometry: a technique to access the information beyond the molecular weight of the analyte," International Journal of Analytical Chemistry, vol. 2012, pp. 1-40, Article ID e282574, 2012.

[20] R. M. Kunwar, K. P. Shrestha, and R. W. Bussmann, "Traditional herbal medicine in Far-west Nepal: a pharmacological appraisal," Journal of Ethnobiology and Ethnomedicine, vol. 6, no. 1, p. 35, 2010.

[21] T. Lakshmi, D. Ezhilarasan, R. Vijayaragavan, S. K. Bhullar, and R. Rajendran, "Acacia catechu ethanolic bark extract induces apoptosis in human oral squamous carcinoma cells," Journal of Advanced Pharmaceutical Technology \& Research, vol. 8, pp. 143-149, 2017.

[22] B. S. Negi and B. P. Dave, "In vitro antimicrobial activity of Acacia catechu and its phytochemical analysis," Indian Journal of Microbiology, vol. 50, no. 4, pp. 369-374, 2010. 
[23] X. Li, H. Wang, C. Liu, and R. Chen, "Chemical constituents of Acacia catechu," Zhongguo Zhong Yao Za Zhi = Zhongguo Zhongyao Zazhi = China Journal of Chinese Materia Medica, vol. 35, pp. 1425-1427, 2010.

[24] X.-C. Li, C. Liu, L.-X. Yang, and R.-Y. Chen, "Phenolic compounds from the aqueous extract of Acacia catechu," Journal of Asian Natural Products Research, vol. 13, no. 9, pp. 826-830, 2011.

[25] V. G. Devi, A. John, R. S. Devi, and V. A. Prabhakaran, "Pharmacognostical studies on Acacia catechu willd and identification of antioxidant principles," International Journal of Pharmacy and Pharmaceutical Sciences, vol. 3, p. 4, 2011.

[26] S. T. Ahamad, T. Lakshmi, S. Rajeshkumar, A. Roy, D. Gurunadhan, and R. Geetha, "Antibacterial activity of taxifolin isolated from Acacia catechu leaf extract-an invitro study," Indian Journal of Public Health Research \& Development, vol. 10, no. 11, p. 3540, 2019.

[27] S. S. Hong, Y.-H. Choi, H.-J. Suh et al., "Flavonoid constituents of Acacia catechu," Journal of Applied Biological Chemistry, vol. 58, no. 2, pp. 189-194, 2015.

[28] S. E. Drewes and D. G. R. Roux, Condensed Tannins Leather Industrie8 Research Institute, Rhodes University, Grahamstowr, South Africa, 1962.

[29] T. Lakshmi, R. Ramasamy, and R. Thirumalaikumaran, "Preliminary phytochemical analysis and in vitro antioxidant, FTIR spectroscopy, anti-diabetic activity of Acacia catechu ethanolic seed extract," Pharmacognosy Journal, vol. 6, pp. 356-362, 2015.

[30] D. Sharma, C. Dangi, and M. Kaur, "A review on pharmacological activities and therapeutic potentials of ficus religiosa (pipal). life science," Indian Journal of Applied Research, vol. 623, pp. 624-626, 2016.

[31] S. Singh and S. Jaiswal, "Therapeutic properties of Ficus religiosa," International Journal of Engineering Research and General Science, vol. 2, pp. 149-158, 2014.

[32] R. Jangde, "Plant profile Ficus religiosa: a review," Research Journal of Science and Technology, vol. 7, no. 4, p. 193, 2015.

[33] N. Akhtar, S. Iqbal, M. F. Shahzad, M. Latif, and F. Iqbal, "Oral supplementation of Ficus religiosa leaf extract adversely affects the selected behavioral aspects of male albino mice," Biologia, vol. 75, no. 12, pp. 2295-2300, 2020.

[34] O. Mousa, P. Vuorela, J. Kiviranta, S. A. Wahab, R. Hiltunen, and H. Vuorela, "Bioactivity of certain Egyptian Ficus species," Journal of Ethnopharmacology, vol. 41, no. 1-2, pp. 71-76, 1994.

[35] R. M. Charde, H. J. Dhongade, M. S. Charde, and E. Z. Building, "Evaluation of antioxidant, wound healing and anti-inflammatory activity of ethanolic extract of leaves of Ficus religiosa," International Journal of Pharmaceutical Sciences and Research, vol. 1, pp. 32-40, 2010.

[36] R. Pandit, A. Phadke, and A. Jagtap, "Antidiabetic effect of Ficus religiosa extract in streptozotocin-induced diabetic rats," Journal of Ethnopharmacology, vol. 128, no. 2, pp. 462-466, 2010.

[37] H. Kaur, D. Singh, B. Singh, and R. K. Goel, “Anti-amnesic effect of Ficus religiosain scopolamine-induced anterograde and retrograde amnesia," Pharmaceutical Biology, vol. 48, no. 2, pp. 234-240, 2010.

[38] M. A. Fernández, B. de las Heras, M. D. García, M. T. Sáenz, and A. Villar, "New insights into the mechanism of action of the anti-inflammatory triterpene lupeol," The Journal of Pharmacy and Pharmacology, vol. 53, no. 11, pp. 1533-1539, 2001.
[39] M. I. Rashid, M. I. Fareed, H. Rashid et al., "Flavonoids and their biological secrets," in Plant and Human Health, Phytochemistry and Molecular Aspects, M. Ozturk and K. R. Hakeem, Eds., Springer International Publishing, Cham, Switzerland, 2019.

[40] M. F. G. Rocha, J. A. Sales, M. G. da Rocha et al., "Antifungal effects of the flavonoids kaempferol and quercetin: a possible alternative for the control of fungal biofilms," Biofouling, vol. 35, no. 3, pp. 320-328, 2019.

[41] A. Ali, M. Jameel, and M. Ali, "New naphthyl esters from the bark of Ficus religiosa Linn," The Natural Products Journal, vol. 4, 2014.

[42] S. M. Manorenjitha, "Chemical profile of Ficus religiosa (Linn.) stem," International Journal of Life Science and Medical Research, vol. 4, pp. 32-37, 2014.

[43] A. Poudel, P. Satyal, and W. N. Setzer, "Composition and bioactivities of the leaf essential oil of Ficus religiosa Linn," American Journal of Essential Oils and Natural Products, vol. 2, pp. 16-17, 2015.

[44] L. Grison-Pigé, M. Hossaert-McKey, J. M. Greeff, and J.-M. Bessière, "Fig volatile compounds-a first comparative study," Phytochemistry, vol. 61, no. 1, pp. 61-71, 2002.

[45] I. K. Makhija, I. P. Sharma, and D. Khamar, "Phytochemistry and pharmacological properties of Ficus religiosa: an overview," Annals of Biological Research, vol. 1, pp. 171-180, 2010.

[46] S. Hossan, B. Agarwala, S. Sarwar, M. Karim, R. Jahan, and M. Rahmatullah, "Traditional use of medicinal plants in Bangladesh to treat urinary tract infections and sexually transmitted diseases," Ethnobotany Research and Applications, vol. 8, pp. 061-74, 2010.

[47] V. Kumar, D. Ahmed, P. S. Gupta, F. Anwar, and M. Mujeeb, "Anti-diabetic, anti-oxidant and anti-hyperlipidemic activities of Melastoma malabathricum Linn. leaves in streptozotocin induced diabetic rats," BMC Complementary and Alternative Medicine, vol. 13, pp. 1-19, 2013.

[48] S. M. Joffry, N. J. Yob, M. S. Rofiee, M. M. R. M. M. Affandi, Z. Suhaili, and F. Othman, "Melastoma malabathricum (L.) smith ethnomedicinal uses, chemical constituents, and pharmacological properties: a review," Evidence-based Complementary and Alternative Medicine, vol. 2012, pp. 620, 2012.

[49] J. Anbu, P. Jisha, R. Varatharajan, and M. Muthappan, "Antibacterial and wound healing activities of Melastoma malabathricum linn," African Journal of Infectious Diseases, vol. 2, pp. 68-73, 2010.

[50] N. Uawonggul, A. Chaveerach, S. Thammasirirak, T. Arkaravichien, C. Chuachan, and S. Daduang, "Screening of plants acting against Heterometrus laoticus scorpion venom activity on fibroblast cell lysis," Journal of Ethnopharmacology, vol. 103, no. 2, pp. 201-207, 2006.

[51] H. A. Hamid, M. M. Yusoff, M. Liu, and M. R. Karim, " $\alpha$-Glucosidase and $\alpha$-amylase inhibitory constituents of Tinospora crispa: isolation and chemical profile confirmation by ultra-high performance liquid chromatography-quadrupole time-of-flight/mass spectrometry," Journal of Functional Foods, vol. 16, pp. 74-80, 2015.

[52] M. P. Mazura, D. Susanti, and M. A. Rasadah, "Antiinflammatory action of components from Melastoma malabathricum," Pharmaceutical Biology, vol. 45, no. 5, pp. 372-375, 2007.

[53] S. S. Mamat, M. Fauzi, F. Kamarolzaman, F. Yahya, N. D. Mahmood, and M. S. Shahril, "Methanol extract of Melastoma malabathricum leaves exerted antioxidant and 
liver protective activity in rats," BMC Complementary and Alternative Medicine, vol. 13, p. 12, 2013.

[54] C. B. Lynn, "Establishment of cell suspension," Production, vol. 117, 2008.

[55] K.-C. Wong, D. M. Hag Ali, and P.-L. Boey, "Chemical constituents and antibacterial activity of Melastoma malabathricum L," Natural Product Research, vol. 26, no. 7, pp. 609-618, 2012.

[56] M. S. Aslam, M. S. Ahmad, and M. A. Ahmad, "An upto-date review on phytochemical constituents and pharmacological activities of Melastoma malabathricum," International Journal of Pharmaceutical Sciences and Research, vol. 8, pp. 76-91, 2017.

[57] D. Kumar, T. Wani, D. Kumar et al., "Analgesic activity of the ethanolic extract of Shorea robusta resin in experimental animals," Indian Journal of Pharmacology, vol. 44, no. 4, p. 493, 2012.

[58] J. Liu, "Pharmacology of oleanolic acid and ursolic acid," Journal of Ethnopharmacology, vol. 49, no. 2, pp. 57-68, 1995.

[59] B. Poornima, "Comparative phytochemical analysis of Shorea robusta Gaertn (oleoresin) WSR to its seasonal collection," Ancient Science of Life, vol. 29, no. 1, pp. 26-28, 2009.

[60] H. Mukherjee, D. Ojha, Y. P. Bharitkar et al., "Evaluation of the wound healing activity of Shorea robusta, an Indian ethnomedicine, and its isolated constituent(s) in topical formulation," Journal of Ethnopharmacology, vol. 149, no. 1, pp. 335-343, 2013.

[61] N. Bainsal, P. Goyal, and J. Singh, "A multi-therapeutic potential indigenous drug," Plant Archives, vol. 20, pp. 3313-3322, 2020.

[62] E. A. Ainsworth and K. M. Gillespie, "Estimation of total phenolic content and other oxidation substrates in plant tissues using Folin-Ciocalteu reagent," Nature Protocols, vol. 2, no. 4, pp. 875-877, 2007.

[63] X. Lu, J. Wang, H. M. Al-Qadiri et al., "Determination of total phenolic content and antioxidant capacity of onion (Allium cepa) and shallot (Allium oschaninii) using infrared spectroscopy," Food Chemistry, vol. 129, no. 2, pp. 637-644, 2011.

[64] I. A. Ahmed, M. A. Mikail, M. bin Ibrahim et al., "Antioxidant activity and phenolic profile of various morphological parts of underutilised Baccaurea angulata fruit," Food Chemistry, vol. 172, pp. 778-787, 2015.

[65] C.-C. Chang, M.-H. Yang, H.-M. Wen, and J.-C. Chern, "Estimation of total flavonoid content in propolis by two complementary colorimetric methods," Journal of Food and Drug Analysis, vol. 10, 2002.

[66] W. Brand-Williams, M. E. Cuvelier, and C. Berset, "Use of a free radical method to evaluate antioxidant activity," $L W T$ Food Science and Technology, vol. 28, no. 1, pp. 25-30, 1995.

[67] H. Fouotsa, A. M. Lannang, C. D. Mbazoa et al., "Xanthones inhibitors of $\alpha$-glucosidase and glycation from Garcinia nobilis," Phytochemistry Letters, vol. 5, no. 2, pp. 236-239, 2012.

[68] K. Khadayat, B. P. Marasini, H. Gautam, S. Ghaju, and N. Parajuli, "Evaluation of the alpha-amylase inhibitory activity of Nepalese medicinal plants used in the treatment of diabetes mellitus," Clinical Phytoscience, vol. 6, no. 1, p. 34, 2020.

[69] M. Balouiri, M. Sadiki, and S. K. Ibnsouda, "Methods for in vitro evaluating antimicrobial activity: a review," Journal of Pharmaceutical Analysis, vol. 6, no. 2, pp. 71-79, 2016.
[70] CLSI, Performance Standards for Antimicrobial Susceptibility Testing: 25th Informational Supplement (M100-S23), Clinical and Laboratory Standards Institute, Wayne, PA, USA, 2015.

[71] J. D. Holman, D. L. Tabb, and P. Mallick, "Employing ProteoWizard to convert raw mass spectrometry data," Current Protocols in Bioinformatics, vol. 46, pp. 13-24, 2014.

[72] T. Pluskal, S. Castillo, A. Villar-Briones, and M. Orešič, "MZmine 2: modular framework for processing, visualizing, and analyzing mass spectrometry-based molecular profile data," BMC Bioinformatics, vol. 11, pp. 1-11, 2010.

[73] M. Katajamaa and M. Orešič, "Processing methods for differential analysis of LC/MS profile data," BMC Bioinformatics, vol. 6, pp. 1-12, 2005.

[74] K. B. Shrestha, "Treeline and vegetation dynamics in response to environmental changes in Nepal, the central Himalaya," Thesis, University of Bergen, Bergen, Norway, 2013.

[75] S. Aryal, M. K. Baniya, K. Danekhu, P. Kunwar, R. Gurung, and N. Koirala, "Total phenolic content, flavonoid content and antioxidant potential of wild vegetables from Western Nepal," Plants, vol. 8, no. 4, p. 96, 2019.

[76] N. Phuyal, P. K. Jha, P. P. Raturi, and S. Rajbhandary, "Total phenolic, flavonoid contents, and antioxidant activities of fruit, seed, and bark extracts of Zanthoxylum armatum DC," The Scientific World Journal, vol. 2020, pp. 1-7, Article ID e8780704, 2020.

[77] K. Sai, R. Thapa, H. P. Devkota, and K. R. Joshi, "Phytochemical screening, free radical scavenging and $\alpha$-amylase inhibitory activities of selected medicinal plants from western Nepal," Medicines (Basel), vol. 6, 2019.

[78] B. Subba, S. Gaire, and K. Raj Sharma, "Analysis of phytoconstituents, antioxidant, and alpha amylase inhibitory activities of persea americana Mill., Rhododendron arboretum Sm. Rubus ellipticus Sm. from Arghakhanchi district Nepal," Asian Journal of Pharmaceutical and Clinical Research, vol. 12, no. 1, p. 301, 2019.

[79] D. J. Newman and G. M. Cragg, "Natural products as sources of new drugs over the 30 years from 1981 to 2010," Journal of Natural Products, vol. 75, no. 3, pp. 311-335, 2012.

[80] E. Barone, V. Calabrese, and C. Mancuso, "Ferulic acid and its therapeutic potential as a hormetin for age-related diseases," Biogerontology, vol. 10, no. 2, pp. 97-108, 2009.

[81] S. I. Rizvi and N. Mishra, "Anti-oxidant effect of quercetin on type 2 diabetic erythrocytes," Journal of Food Biochemistry, vol. 33, no. 3, pp. 404-415, 2009.

[82] B. Kis, S. Avram, I. Z. Pavel et al., "Recent advances regarding the phytochemical and therapeutic uses of populus nigra L. Buds," Plants, vol. 9, no. 11, p. 1464, 2020.

[83] F. Mujeeb, P. Bajpai, and N. Pathak, "Phytochemical evaluation, antimicrobial activity, and determination of bioactive components from leaves of aegle marmelos," Biomed Research International, vol. 2014, 2014.

[84] K. Balamurugan, A. Nishanthini, and V. R. Mohan, “Antidiabetic and antihyperlipidaemic activity of ethanol extract of Melastoma malabathricum Linn. leaf in alloxan induced diabetic rats," Asian Pacific Journal of Tropical Biomedicine, vol. 4, pp. S442-S448, 2014.

[85] T. Tunsaringkarn, A. Rungsiyothin, and N. Ruangrungsi, " $\alpha$-glucosidase inhibitory activity of water soluble extract from Thai mimosaceous plants," Journal of Health Research, vol. 1, pp. 54-63, 2009, https://www.tci-thaijo.org/index. php/phjbuu/article/view/45607.

[86] A. K. Keshari, G. Kumar, P. S. Kushwaha et al., "Isolated flavonoids from Ficus racemosa stem bark possess 
antidiabetic, hypolipidemic and protective effects in albino Wistar rats," Journal of Ethnopharmacology, vol. 181, pp. 252-262, 2016.

[87] P. Singh, V. K. Singh, and A. K. Singh, "Molecular docking analysis of candidate compounds derived from medicinal plants with type 2 diabetes mellitus targets," Bioinformation, vol. 15, no. 3, pp. 179-188, 2019.

[88] L. R. Fukumoto and G. Mazza, "Assessing antioxidant and prooxidant activities of phenolic compounds $\dagger$," Journal of Agricultural and Food Chemistry, vol. 48, no. 8, pp. 35973604, 2000.

[89] A. I. Martinez-Gonzalez, Á. G. Díaz-Sánchez, L. A. d. l. Rosa, C. L. Vargas-Requena, I. Bustos-Jaimes, and a. E. AlvarezParrilla, "Polyphenolic compounds and digestive enzymes: in vitro non-covalent interactions," Molecules, vol. 22, no. 4, p. 669, 2017.

[90] M. N. Sarian, Q. U. Ahmed, S. Z. Mat So'ad et al., “Antioxidant and antidiabetic effects of flavonoids: a structureactivity relationship based study," BioMed Research International, vol. 2017, pp. 1-14, 2017.

[91] A. C. de Camargo, B. T. Favero, M. C. Morzelle et al., "Is chickpea a potential substitute for soybean? phenolic bioactives and potential health benefits," International Journal of Molecular Sciences, vol. 20, no. 11, p. 2644, 2019.

[92] A. C. da C. Pinaffi, G. R. Sampaio, M. J. Soares, F. Shahidi, A. C. de Camargo, and E. A. F. S. Torres, "Insoluble-bound polyphenols released from guarana powder: inhibition of alpha-glucosidase and proanthocyanidin profile," Molecules, vol. 25 , no. 3, p. $679,2020$.

[93] P. Deepa, K. Sowndhararajan, S. Kim, and S. J. Park, “A role of Ficus species in the management of diabetes mellitus: a review," Journal of Ethnopharmacology, vol. 215, pp. 210232, 2018.

[94] M. Dashtdar, M. R. Dashtdar, B. Dashtdar, M. k. shirazi, and S. A. Khan, "In-vitro, anti-bacterial activities of aqueous extracts of Acacia catechu (L.F.)Willd, castanea sativa, ephedra sinica stapf and shilajita mumiyo against gram positive and gram negative bacteria," Journal of Pharmacopuncture, vol. 16, no. 2, pp. 15-22, 2013.

[95] S. Joshi, Y. P. Subedi, and S. K. Paudel, "Antibacterial and antifungal activity of heartwood of acacia catechu of Nepal," Journal of Nepal Chemical Society, vol. 27, pp. 94-99, 2011.

[96] J. D. Patel, V. Kumar, and S. A. Bhatt, "Antimicrobial screening and phytochemical analysis of the resin part of Acacia catechu," Pharmaceutical Biology, vol. 47, no. 1, pp. 34-37, 2009.

[97] M. L. Saini, R. Saini, S. Roy, and A. Kumar, "Comparative pharmacognostical and antimicrobial studies of Acacia species (Mimosaceae)," Journal of Medicinal Plants Research, vol. 2, pp. 378-386, 2008.

[98] S. B. Chandrasekar, M. Bhanumathy, A. Pawar, and T. Somasundaram, "Phytopharmacology of Ficus religiosa," Pharmacognosy Reviews, vol. 4, no. 8, pp. 195-199, 2010.

[99] Z. A. A. Alnajar, M. A. Abdulla, H. M. Ali, M. A. Alshawsh, and A. H. A. Hadi, "Acute toxicity evaluation, antibacterial, antioxidant and immunomodulatory effects of melastoma malabathricum," Molecules, vol. 17, no. 3, pp. 3547-3559, 2012.

[100] D. Biswas, B. Mahalakshmi, B. Samelu, M. Devadas, and S. V. S. Kumar, "Antimicrobial activity of ethanol extracts and isolated fractions shorea robusta gaertn $\mathrm{f}$ and dipterocarpus turbinatus gaertn $\mathrm{f}$," Pharmacognosy Communications, vol. 10, no. 2, pp. 102-107, 2020.
[101] I. N. Ismail, "Antibacterial activity of flower, leave and stem extract of melastoma decemfidum," International Journal of Life Sciences Biotechnology and Pharma Research, vol. 6, p. 5, 2017, http://www.ijlbpr.com/uploadfile/2017/ 0706/20170706020046974.pdf.

[102] A. Aleem and H. Kabir, "Review on swertia chirata as traditional uses to its pyhtochemistry and phrmacological activity," Journal of Drug Delivery and Therapeutics, vol. 8, no. 5-s, pp. 73-78, 2018.

[103] V. Kumar and J. Van Staden, "A review of swertia chirayita (gentianaceae) as a traditional medicinal plant," Frontiers in Pharmacology, vol. 6, 2016.

[104] M. M. Cowan, "Plant products as antimicrobial agents," Clinical Microbiology Reviews, vol. 12, no. 4, pp. 564-582, 1999, https:// www.ncbi.nlm.nih.gov/pmc/articles/PMC88925/.

[105] L. Boulekbache-Makhlouf, S. Slimani, and K. Madani, “Total phenolic content, antioxidant and antibacterial activities of fruits of Eucalyptus globulus cultivated in Algeria," Industrial Crops and Products, vol. 41, pp. 85-89, 2013.

[106] M. A. Hye, M. A. Taher, M. Y. Ali, M. U. Ali, and S. Zaman, "Isolation of $(+)$-catechin from acacia catechu (cutch tree) by a convenient method," Journal of Scientific Research, vol. 1, no. 2, pp. 300-305, 2009.

[107] T. A. Ibrahim, R. A. E. Dib, H. M. Al-Youssef, and M. Amina, "Chemical composition and antimicrobial and cytotoxic activities of antidesm abunius L," Pakistan Journal of Pharmaceutical Sciences, vol. 11, 2019.

[108] D. Shen, Q. Wu, M. Wang, Y. Yang, E. J. Lavoie, and J. E. Simon, "Determination of the predominant catechins in acacia catechu by liquid chromatography/electrospray ionization-mass spectrometry," Journal of Agricultural and Food Chemistry, vol. 54, no. 9, pp. 3219-3224, 2006.

[109] Y. Wang, P. d. B. Harrington, and P. Chen, "Quantitative analysis of proanthocyanidins in cocoa using cysteamineinduced thiolysis and reversed-phase UPLC," Analytical and Bioanalytical Chemistry, vol. 412, no. 18, pp. 4343-4352, 2020.

[110] C. Zhan, A. Xiong, D. Shen, L. Yang, and Z. Wang, "Characterization of the principal constituents of danning tablets, a Chinese formula consisting of seven herbs, by an UPLC-DAD-MS/MS approach," Molecules, vol. 21, no. 5, p. $631,2016$.

[111] E. C. Bate-Smith and T. C. Whitmore, "Chemistry and taxonomy in the dipterocarpaceae," Nature, vol. 184, no. 4689 , pp. 795-796, 1959.

[112] J. B. Harborne, "The evolution of flavonoid pigments in plants," Comparative Phytochemistry, vol. 24, pp. 271-295, 1996.

[113] C. Giorio, E. Moyroud, B. J. Glover, P. C. Skelton, and M. Kalberer, "Direct surface analysis coupled to highresolution mass spectrometry reveals heterogeneous composition of the cuticle ofhibiscus trionumpetals," Analytical Chemistry, vol. 87, no. 19, pp. 9900-9907, 2015.

[114] A. Petsalo, J. Jalonen, and A. Tolonen, "Identification of flavonoids of Rhodiola rosea by liquid chromatographytandem mass spectrometry," Journal of Chromatography A, vol. 1112, no. 1-2, pp. 224-231, 2006.

[115] X. Fu, X.-C. Li, Y.-H. Wang et al., "Flavonol glycosides from the South African medicinal PlantSutherlandia frutescens," Planta Medica, vol. 76, no. 02, pp. 178-181, 2010.

[116] W. Wang, J. Dang, Y. Shao et al., "A novel chromatographic separation method for rapid enrichment and isolation of novel flavonoid glycosides from Sphaerophysa salsula," 
Journal of Separation Science, vol. 43, no. 21, pp. 4018-4027, 2020.

[117] A. L. Santos, M. G. Soares, L. S. de Medeiros, M. J. P. Ferreira, and P. Sartorelli, "Identification of flavonoid-3-O-glycosides from leaves of Casearia arborea (Salicaceae) by UHPLCDAD-ESI-HRMS/MS combined with molecular networking and NMR," Phytochemical Analysis, vol. 8, 2021.

[118] N. L. Vuković, M. D. Vukić, G. T. Đelić, M. M. Kacaniova, and M. Cvijović, "The investigation of bioactive secondary metabolites of the methanol extract of eryngium amethystinum," Kragujevac Journal of Science, vol. 113, pp. 113-129, 2018.

[119] W. Liu, J. Huang, F. Zhang, C. Zhang, R. Li, and Y. Wang, "Comprehensive profiling and characterization of the absorbed components and metabolites in mice serum and tissues following oral administration of qingfei paidu decoction by UHPLC-Q-exactive-Orbitrap HRMS," 2020.

[120] D. Şöhretoğlu, M. K. Sakar, S. A. Sabuncuoğlu, H. Özgüneş, and O. Sterner, "Antioxidant galloylated flavonoids from Geranium tuberosum L. subsp. tuberosum," Turkish Journal of Chemistry, vol. 33, pp. 685-692, 2009.

[121] R. E. March and X.-S. Miao, "A fragmentation study of kaempferol using electrospray quadrupole time-of-flight mass spectrometry at high mass resolution," International Journal of Mass Spectrometry, vol. 231, no. 2-3, pp. 157-167, 2004.

[122] S. I. Alqasoumi, A. J. Al-Rehaily, and M. S. Abdel-Kader, "Phytochemical and pharmacological study of Ficus cordata growing in Saudi Arabia," Pakistan Journal of Pharmaceutical Sciences, vol. 27, no. 6, pp. 1841-9, 2014. 